\title{
Foreground and background in the narrative discourse of Luke's Gospel: Some remarks on the function of the Greek imperfect and pluperfect indicative tense-forms ${ }^{1}$
}

\author{
Herman du Toit \\ Department of Old and New Testament Studies, University of the Free State, South Africa \\ E-mail: hcdutoit@icon.co.za
}

\begin{abstract}
The distinction between foreground and background in narrative discourse is a pervasive phenomenon in the literatures of the world, and languages have a variety of devices to indicate this distinction. The use of the tense-forms of the verb for this purpose has been studied in a variety of languages, including the Greek of the New Testament.
\end{abstract}

The aim of this study is to explore, describe, and classify the functions of the imperfect and pluperfect indicative in the Gospel of Luke's narrative discourse. The study is restricted to narrative proper (which includes embedded narratives, such as the parables of Jesus), but excludes direct and indirect discourse, and comments by the author of the Gospel.

The findings are that the main function of the imperfect in the Gospel of Luke's narrative discourse is to provide background information. This is related to the imperfect's "imperfective" aspect and its characteristic linking to another verbal utterance, which also promotes cohesion in the text. The imperfect's main specific use is to provide background information in the form of setting the scene for events that follow in the main storyline. It is also used in the introduction of participants in a scene, to provide supplementary details, in epilogues, and in explanatory clauses. In a few instances, the imperfect expresses foreground information.

The pluperfect is always used for background information. This is related to its characteristic of describing a continuing state in the past which is the result of an event in the past. The pluperfect's specific uses are to set the scene for mainline events that follow, together with the imperfect; to provide supplementary details about persons, events, etc. in the main storyline; and to explain the reason for events in the main storyline.

Keywords: narrative discourse; imperfect indicative; pluperfect indicative; Greek; New Testament

\footnotetext{
${ }^{1}$ A preliminary version of this paper was presented at the International Meeting of the Society of Bible Literature in Rome, Italy, 1-5 July 2019.
} 


\section{The aim and scope of the paper}

The aim of the research that underlies this paper is to investigate, describe, and classify the functions of the imperfect and pluperfect indicative tense-forms (henceforth, "imperfect" and "pluperfect", respectively) in indicating foreground and background information in the narrative discourse of the Gospel of Luke (henceforth, "Luke"). The study is confined to narrative proper in Luke, i.e. the main storyline and offline information in narrative discourse. The study also includes embedded narratives, such as the parables of Jesus, but excludes direct and indirect discourse, and comments by the author.

This paper is the first attempt at a detailed analysis of the function of the imperfect to denote foreground and background in Luke as a whole. Although the backgrounding function of the imperfect in the New Testament (henceforth, "NT") is relatively well-known, the various subcategories of meaning of the concept of 'background', as it applies specifically to Luke, need to be identified and discussed. The study is also new in the sense that it attempts to provide further evidence that the function of the imperfect in Luke's narrative proper is not restricted to background information, but that it can denote foreground in certain circumstances.

Although the function of the few occurrences of the pluperfect in Luke's narrative proper has received some attention, ${ }^{2}$ this paper offers a number of new perspectives.

\section{The foreground vs. background distinction in narrative discourse}

The foreground vs. background distinction in narrative discourse is defined in a number of ways in literature studies. The definition used in this paper derives mainly from that of Callow (1974: $52-53),{ }^{3}$ who relates foreground to thematic prominence. According to Callow, thematic material "carries the discourse forward, contributes to the progression of the narrative or argument [and] develops the theme of the discourse". Non-thematic or background material "serves as a commentary on the theme but does not itself contribute directly to the progression of the theme $[\ldots]$ [It] fills out the theme but does not develop it".

In addition to thematic prominence, a number of other indicators have been proposed for foreground and background in narrative discourse. According to Fleischmann (1985: 857), the "conventional view" in many discourse studies - such as those of Talmy (1978), Hopper (1979a, 1979b), and Hopper and Thompson (1980) - is that:

those events which constitute the 'main line' of the story are typically encoded as action verbs, aspectually perfective, while supportive material is typically packaged in the form of stative or durative predicates, aspectually imperfective. ${ }^{4}$

Other indicators that have been proposed include morphosyntactic devices, involving degrees of transitivity, ${ }^{5}$ events vs. non-events, ${ }^{6}$ voice, and word order. ${ }^{7}$ The indicators are not

\footnotetext{
${ }^{2}$ Cf. Campbell (2007: 215-217).

${ }^{3}$ Quoted by Levinsohn (2000: 169).

${ }^{4}$ Cf. also Dry (1992: 441).

${ }^{5}$ Cf. Hopper and Thompson (1980: 252, in Dooley and Levinsohn 2000: 41).

${ }^{6}$ Cf. Grimes (1975: 51-70).

${ }^{7}$ Hopper (1979b: 219-234, in Du Toit 2017: 212, fn. 9).
} 
mutually exclusive, and often co-occur with specific tense-forms of the verb in indicating foreground and background.

In the field of NT studies, considerable research has been undertaken during the last few decades on the foreground-background distinction in narrative discourse and its relationship to specific Greek tense-forms with their accompanying aspectual and time characteristics. This was mostly due to the impetus of the work of Porter (1989) and Fanning (1990) on the aspectual and temporal characteristics of the Greek verb-tenses, and the ensuing upsurge of interest in these areas. ${ }^{8}$ In some instances, research was done on extensive corpuses, such as books or chapters of the NT. ${ }^{9}$

It is now important to discuss briefly the view of the aspectual and time characteristics of the imperfect and pluperfect tense-forms which is used in this study on narrative proper in Luke.

\subsection{The imperfect}

Scholars generally agree that the aspect of the imperfect is "imperfective". For example, "imperfective aspect" is described by Fanning (1990: 27) as an internal viewpoint "without reference to the beginning or end-point of the action, but with a focus instead on its internal structure or make-up" 10 . This is in contrast with the aorist, of which the aspect is generally viewed as perfective.

However, it should be added that the imperfect has other important characteristics related to its aspect. In a recent paper on the function of imperfect tense-form in narrative discourse in John's Gospel (Du Toit 2017: 215), I drew attention to the view of Seiler (1952: 113) that the imperfect in Modern Greek always establishes a reference to another verbal utterance. ${ }^{11}$ Bakker (1966: 26), who applies Seiler's view to NT Greek, defines the "chief characteristic" of the imperfect as follows: "[The imperfect] always has a relationship with another verbal notion, a point from which, around which, or before which the speaker views the process in its perspective". To this should be added the important remarks of Rijksbaron (1988: 237) that the "non-closed" and "ongoing" nature of the imperfect "raises expectations as to what is going to happen next" and "serves as a powerful means to establish cohesion in a text".

With regard to the time-reference of the imperfect, there is no agreement among scholars on whether the imperfect has an inherent characteristic to refer to past time, or whether the reference to the past (in contexts where the imperfect appears) is due to deictic or aspectual features (e.g. remoteness; Du Toit 2017: 218). ${ }^{12}$ This issue is not of crucial importance to the present topic, and will not be debated here. In this paper, it is assumed, as in Du Toit (2017:218), that time-reference is integral to the imperfect in narrative proper, and refers to past time.

\footnotetext{
${ }^{8}$ Cf. Porter (1994: 23), Levinsohn (2000: 169-196), and Campbell (2007, 2008).

${ }^{9}$ Cf. Pennington and Van Court (2006) on the Gospel of Matthew; Mathewson (2008) on Revelation 5 and Mathewson (2010) on Revelation; Johnson (2010) on the Gospel of Luke and Acts; Decker (2013) on chapters 1 to 8 of the Gospel of Mark; and Du Toit (2017) on the Gospel of John.

${ }^{10}$ See also Campbell (2007: 77-79).

${ }^{11}$ For more information on Seiler's view, see Du Toit (2017: 215-216).

${ }^{12}$ See Du Toit $(2017: 218)$ for literature on the different views.
} 


\subsection{The pluperfect}

The view of the pluperfect's temporal and aspectual characteristics that is used in this paper is formulated by Wallace (1996: 583) as follows: "[...] The force of the pluperfect is that it describes an event that, completed in the past, has results that existed in the past as well (in relation to the time of speaking)" "13, and "The pluperfect describes the state resulting from the event as continuing" ${ }^{14}$. Wallace distinguishes the following uses of the pluperfect:

(i) Intensive pluperfect: According to Wallace (1996: 584), "this use of the pluperfect places the emphasis on the results that existed in past time [...] It is different from an imperfect in that the imperfect describes the event itself as progressive, while the pluperfect only describes the state resulting from the event as continuing". Cf. the following examples from Wallace (1996:

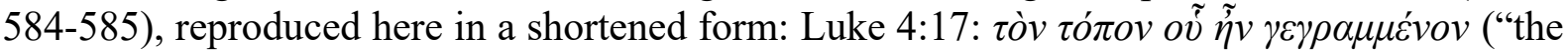

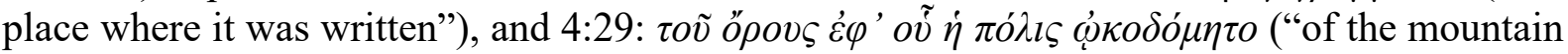
on which the city was built").

(ii) Extensive pluperfect: In this use, the pluperfect emphasizes "the completion of an action in past time, without focusing as much [original italics] on the existing results" (Wallace 1996: 585). Cf. the following examples from Wallace (1996: 585), reproduced here in a shortened

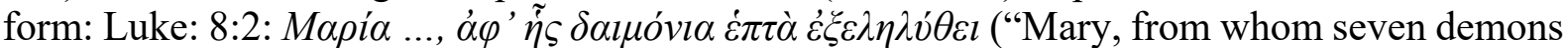

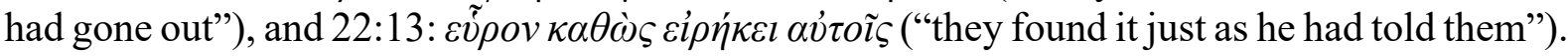

(iii) Pluperfect with a simple past force: This use is restricted to a number of verbs that "occur frequently (or exclusively) in the perfect and pluperfect tenses without the usual aspectual significance" (Wallace 1996: 586). These verbs are typically stative verbs, and include the following: oi $\delta \alpha$ ("I know"), ï $\sigma \tau \mu l$ ("I put"), $\varepsilon i \iota \omega \theta \alpha$ ("I am in the habit of"), $\pi \varepsilon i \theta \omega$ ("I persuade"), and $\pi \alpha \rho i \sigma \tau \eta \mu \imath$ ("I cause to be in a place"). Examples from Luke are 6:8: $\alpha \dot{\tau} \tau \dot{c} \varsigma \delta \dot{\varepsilon}$

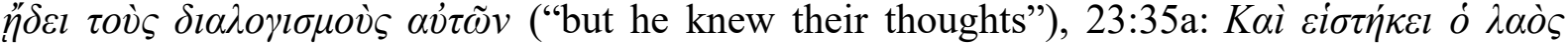
$\theta \varepsilon \omega \rho \tilde{\omega} v$ ("And the people stood by, watching"), etc.

\section{The function of the imperfect and pluperfect to indicate background information}

The dominant tense-forms in the indicative mood that occur in narrative discourse in Luke (excluding direct and indirect discourse, and comments by the author) are the aorist (838 times) ${ }^{15}$ and imperfect (329 times in its simple, i.e. non-periphrastic, form). ${ }^{16}$ There are considerably fewer occurrences of the other tense-forms: the pluperfect occurs 12 times in its simple form, and 4 times in its periphrastic form; the historical present 12 times; and the perfect indicative twice in its simple form. ${ }^{17}$

\footnotetext{
13 The view of the pluperfect as indicating past time is not shared by those linguists who view the Greek verb-tenses as indicating aspect only, not time as well. For example, according to Campbell (2007: 237), the pluperfect "semantically encodes imperfective aspect and heightened remoteness".

${ }^{14}$ The view of the pluperfect's aspect as indicating a state is also shared by Porter (1989: 289) and McKay (1994: 322).

${ }^{15}$ Statistics based on Campbell (2007: 111).

${ }^{16}$ Statistics based on Campbell (2007: 79).

17 These figures include narratives embedded within direct discourse, such as parables. Cf. Luke 15:11-32, 16:19$31,18: 2-5$, and 19:12-27.
} 


\subsection{Setting the scene ${ }^{18}$}

Setting the scene, which is by nature a non-event and background information, seems to be the major function of the imperfect in Luke's narrative proper. In this case, one or more imperfects (and/or a pluperfect) provide the setting, after which the main storyline begins, carried by aorist indicatives and/or historical presents.

This is illustrated by the passage below (Luke 6:19-31), which is part of Jesus' words introduced by $\varepsilon \tilde{i} \pi \varepsilon v$ ("he said") in 16:15. This passage is an example of an embedded narrative, in this case, a parable. (In the diagrams below, the following conventions are used: an aorist indicative and its translation are indicated in bold; an imperfect and its translation appear in bold and italics; a pluperfect indicative and its translation are indicated in bold and are single-underlined, and a historical present and its translation appear in bold and are double-underlined.)

\section{$\underline{\text { Luke 16:19-31 }}{ }^{19}$}

\begin{tabular}{|c|c|}
\hline 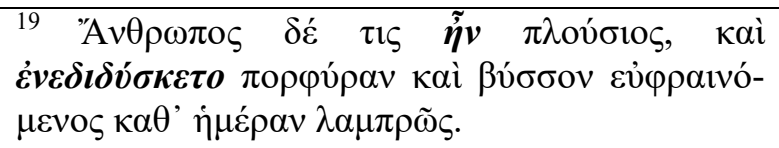 & $\begin{array}{l}{ }^{19} \text { There was a rich man, and he used to dress in } \\
\text { purple and fine linen and celebrated splendidly } \\
\text { every day. }\end{array}$ \\
\hline 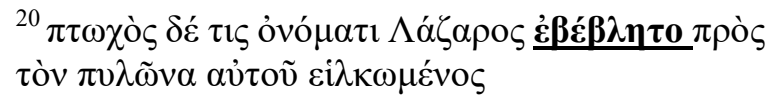 & $\begin{array}{l}{ }^{20} \text { And a certain poor man named Lazarus was } \\
\text { laid at his gate, full of sores }\end{array}$ \\
\hline 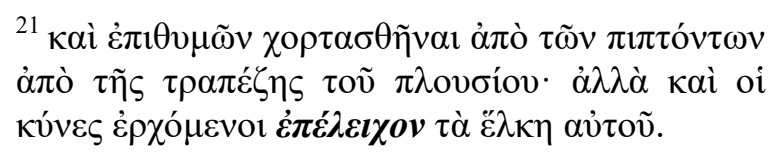 & $\begin{array}{l}{ }^{21} \text { and longing to fill himself from what fell from } \\
\text { the rich man table, and even the dogs would come } \\
\text { and lick his sores. }\end{array}$ \\
\hline 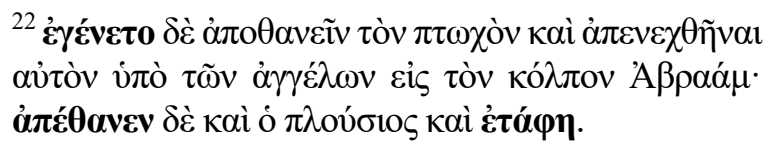 & $\begin{array}{l}{ }^{22} \text { The poor man died and was carried away by the } \\
\text { angels to Abraham's bosom. The rich man also } \\
\text { died and was buried. }\end{array}$ \\
\hline 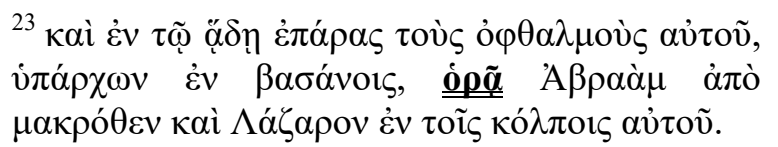 & $\begin{array}{l}{ }^{23} \text { And in Hades, being in torment, he looked up and } \\
\underline{\underline{\text { aw }} \text { Abraham far away and Lazarus in his bosom. }}\end{array}$ \\
\hline 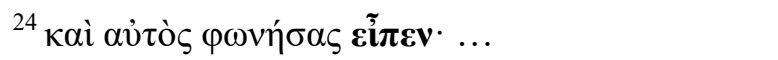 & ${ }^{24}$ And he called out and said ... (Direct discourse) \\
\hline 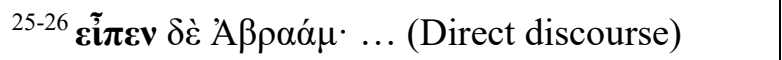 & ${ }^{25-26}$ But Abraham said ... (Direct discourse) \\
\hline${ }^{27-28} \boldsymbol{\varepsilon} \tilde{\boldsymbol{i}} \boldsymbol{\pi} \boldsymbol{\varepsilon} \boldsymbol{v} \delta \dot{\varepsilon} \cdot \ldots$ (Direct discourse) & 27-28 Then he said ... (Direct discourse) \\
\hline 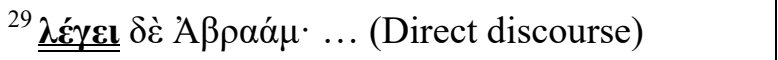 & ${ }^{29}$ But Abraham said ... (Direct discourse) \\
\hline${ }^{30}$ ó $\delta \dot{\varepsilon} \boldsymbol{\varepsilon} \mathbf{\varepsilon} \boldsymbol{\pi} \boldsymbol{\varepsilon} \mathbf{v} \cdot \ldots$ (Direct discourse) & ${ }^{30}$ And he said ... (Direct discourse) \\
\hline${ }^{31} \boldsymbol{\varepsilon} \tilde{\boldsymbol{I}} \boldsymbol{\varepsilon} \boldsymbol{\varepsilon v} \delta \grave{\varepsilon} \alpha \hat{\jmath} \tau \tilde{\omega} \cdot \ldots$ (Direct discourse) & ${ }^{31}$ But he said to him ... (Direct discourse) \\
\hline
\end{tabular}

\footnotetext{
${ }^{18}$ The term "setting" is used here to describe the time, place, or circumstances of the mainline events of a narrative (Grimes 1975: 63).

${ }^{19}$ The translations of the Greek text in this example and others in the paper are my own. The following translations were consulted as part of the translation process: The Holy Bible: King James Version ([1611], 1769), Die Bybel: 1933/1953 translation, The Holy Bible: New King James Version (1982), Die Bybel: 1983 translation, The Holy Bible: New Revised Standard Version of the Bible (1989), The New Jerusalem Bible: Reader's Edition (1990), The New American Standard Bible (1995), The New English Translation (2006), The Holy Bible: New Living Translation (2007), New American Bible (2010), The Holy Bible: English Standard Version (2011), The Holy Bible: New International Version (2011), and Nuwe Testament en Psalms: 'n Direkte Vertaling (2014).
} 
The setting for the story in Luke 16:19-31 begins with the introduction of two major participants. The rich man is introduced in v. 16:19a by $\ddot{\alpha} v \theta \rho \omega \pi o \varsigma \delta \varepsilon \dot{\varepsilon} \tau \iota \varsigma \tilde{\eta} v \pi \lambda o v ́ \sigma l o \varsigma$ ("there was a rich man"), in which the imperfect $\tilde{\eta} v$ ("there was") occurs as the main verb, indicating an ongoing state in the past. ${ }^{20}$ The setting continues with a description of the habits of the rich

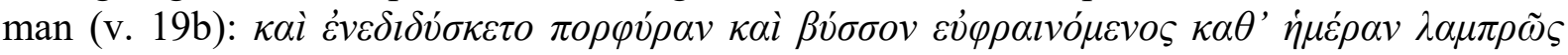
("and he used to dress in purple and fine linen and celebrated splendidly every day"), which contains the customary imperfect $\dot{\varepsilon} v \varepsilon \delta l \delta v$ $\sigma \kappa \varepsilon \tau o$ ("he used to dress") as main verb. The poor man is introduced in v. 20, which contains the pluperfect $\dot{\varepsilon} \beta \dot{\varepsilon} \beta \lambda \eta \tau o$ ("he was laid") as main verb. This is also part of the setting, describing a state in the past that resulted from the action of being laid down at the gate. The setting continues in v. 21, where another customary imperfect $\dot{\varepsilon} \pi \dot{\lambda} \lambda \varepsilon l \chi O v$ ("they [the dogs] would lick") is the main verb. A number of present participles are

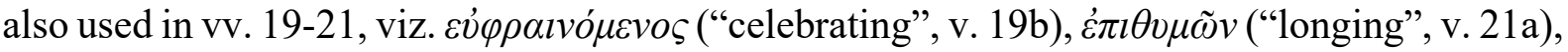

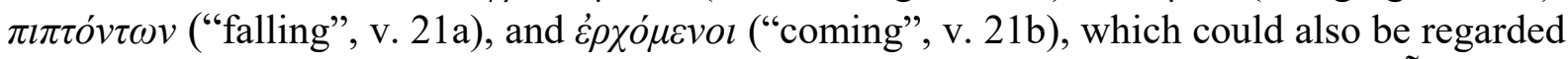
as indicating customary actions as part of the setting. The progressive imperfect $\tilde{\eta} v$ ("there

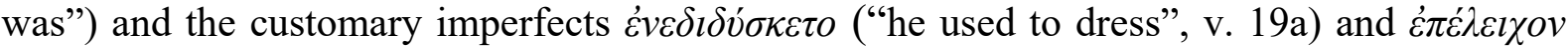
("they [the dogs] would lick", v. 21b) fit in well as part of the background setting for the mainline event(s) that follow later on. The imperfects create an expectation of something to happen due to their inherent characteristic of being linked to another verbal utterance. In this way, they contribute to cohesion in the text.

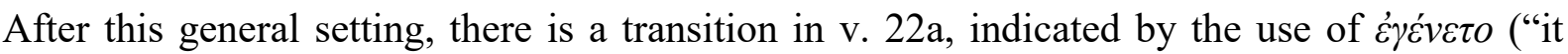
happened") and the particle $\delta \varepsilon$ ("and"). ${ }^{21}$ The story now moves to more specific background information for the mainline events that follow in vv. 22b-31. The specific background information is provided by the two infinitival clauses: $\dot{\alpha} \pi \sigma \theta \alpha v \varepsilon \tilde{\imath} v \tau \dot{o} v \pi \tau \omega \chi \delta$ 'v ("the poor man

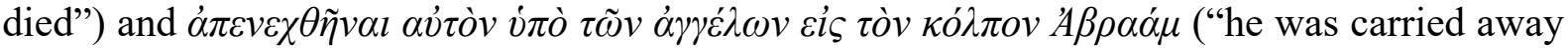
by the angels to Abraham's bosom") in v. 22a. ${ }^{22}$

In the main storyline, the focus is first on the death and burial of the rich man (Luke 16:22b-23), and then on the discussion between him and Abraham (vv. 24-31). There is also a concomitant change in the verb-tenses used: whereas imperfects and a pluperfect feature in the broader setting of the narrative (vv. 19-21), the main storyline (vv. 22b-31) is carried by aorist indicatives and historical presents. Two aorist indicatives - $\dot{\alpha} \pi \dot{\theta} \theta \alpha v \varepsilon v$ ("he died") and $\dot{\varepsilon} \tau \dot{\alpha} \varphi \eta$ ("he was buried") are used in v. 22b, and five instances of $\varepsilon \tilde{i} \pi \varepsilon v$ ("he said") in vv. 24-31 to introduce the sections of direct speech in the discussion between the rich man and Abraham. The rest of the main story is carried by historical presents: $\delta \rho \tilde{\alpha}$ ("he saw", v. 23b) and $\lambda \dot{\varepsilon} \gamma \varepsilon l$ ("he said", v. 29).

The overall pattern of the narrative in Luke 16:19-31, where the broader scene is set mainly by

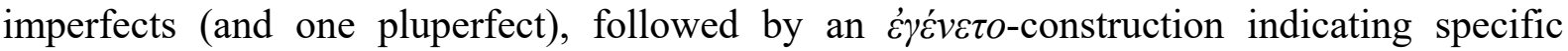

\footnotetext{
${ }^{20}$ There is no evidence in Luke, as in the Gospel of John, that the imperfect tense-forms of the verb cipi ("I am"), which is morphologically deficient, are aspectually vague. For more information, see Du Toit (2017: 220, fn. 25).

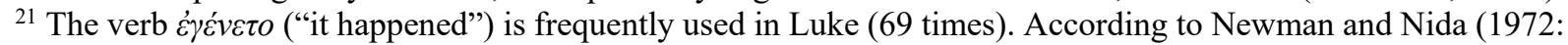

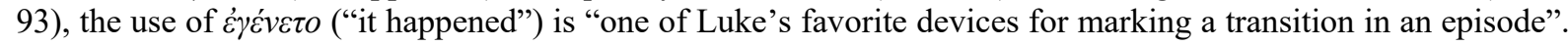
Cf. Levinsohn (2000:177-179) for a more detailed discussion of the $\dot{\gamma} \gamma \varepsilon \dot{v} \varepsilon \tau o$-construction. The particle $\delta \varepsilon$ ("and") in Luke 16:22a also signals "a new step or development in the author's story or argument" (Levinsohn 2000: 72). ${ }^{22}$ Other examples of the use of infinitival constructions to indicate specific background circumstances after É $\gamma \varepsilon \dot{\varepsilon} \varepsilon \tau o$ ("it happened") occur in Luke 3:21b, 22a, and 22b. Cf. also Acts 9:32, 9:37, 11:26b, and 14:1. The construction is not common in Luke, as pointed out by Levinsohn (2000: 177-178); a sentence with an indicative is preferred for this purpose, as in e.g. 1:8-9, 2:6, and 8:22, etc. Cf. also Mark 1:9 and 4:4.
} 
background circumstances as part of the setting, after which the mainline story commences, occurs in several instances in Luke (cf. also e.g. 5:15-19ff, 19:47-20:2ff, and 24:13-17f, etc.). ${ }^{23}$

\subsection{Introduction of participants}

The introduction of participants, which is also by nature a non-event and as such background information, is done in a number of ways in the NT. ${ }^{24}$ Levinsohn (2000: 134) points out that in cases where a participant is introduced in a new section of an ongoing story, a sentence with presentational articulation is most often used. Cf. his example from Acts 9:10a-b: ' $H v \delta \varepsilon$ ' $\tau \iota \varsigma$

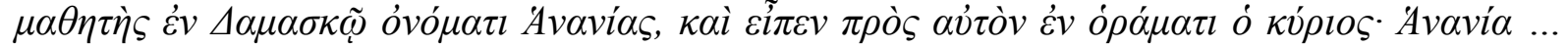
("Now there was a certain disciple in Damascus, named Ananias; and the Lord said to him in a

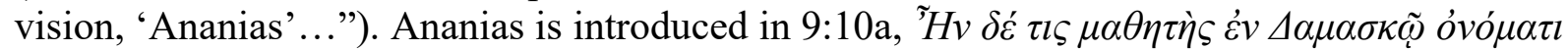
Avavias ("There was a certain disciple in Damascus, named Ananias"), as a participant in the new scene (9:10-18). The sentence in 9:10a has presentational articulation, and the tense-form used is the imperfect $\tilde{\eta} v$ ("there was").

The introduction of participants by means of a sentence with presentational articulation in which

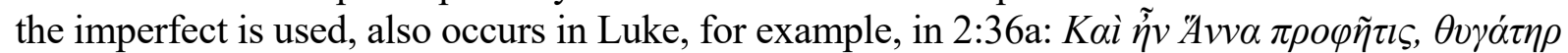

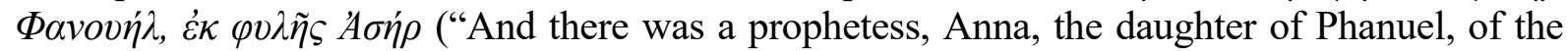
tribe of Asher"). This is followed in 2:36b and 37 by the setting for the main events in v. $38 .{ }^{25}$

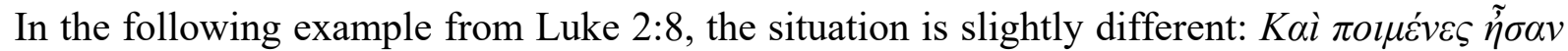

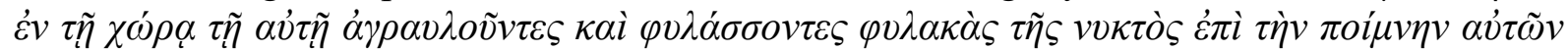
("And there were shepherds in the same region staying out in the fields and guarding their flock by night"). This sentence has presentational articulation and contains two periphrastic imperfects $-\tilde{\eta} \sigma \alpha v \ldots \dot{\alpha} \gamma \rho \alpha v \lambda \sigma \tilde{v} v \tau \varepsilon \varsigma \ldots \varphi v \lambda \dot{\alpha} \sigma \sigma o v \tau \varepsilon \varsigma$ ("they were staying out and guarding"). In this case, the introduction of the main participants (the shepherds) and the setting for the mainline story in vv. 9-18 are done in the same sentence. ${ }^{26}$

In some instances, the attention prompter $i \delta o v$ ("look") is used together with the imperfect in a sentence with presentational articulation, and serves to highlight the introduction of a

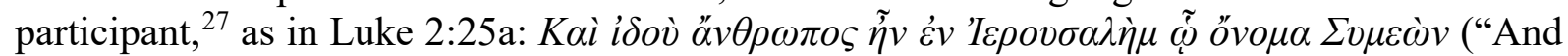
look, there was a man in Jerusalem called Simeon"). The introduction of Simeon and the first part of the setting are again done in the same clause $(2: 25 \mathrm{a})$. The rest of the setting occurs in $2.25 \mathrm{~b}-\mathrm{c}$, and $2: 26$. In $2.25 \mathrm{c}$, the imperfect $\tilde{\eta} v$ ("he [Simeon] was") is used, and in 2:26, the periphrastic pluperfect $\tilde{\eta} v$... $\kappa \varepsilon \chi \eta \mu \alpha \tau \iota \sigma \mu \varepsilon ́ v o v$ ("it had been revealed"). The imperfect in v. 25c is progressive, indicating a state ongoing at the time, and the pluperfect is extensive, meaning that the emphasis is on the "completion of an action in past time, without as much [original italics] on the result" (Wallace 1996: 585). ${ }^{28}$

\footnotetext{
${ }^{23}$ The same narrative pattern also occurs in Acts. See e.g. 2:1-4 and 9:31-34. In the Gospel of John, there are considerably

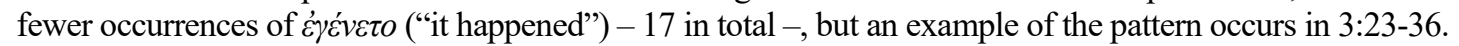

${ }^{24}$ Cf. Levinsohn (2000: 134-135) for a brief discussion of the various ways in which participants are introduced.

${ }^{25}$ See section 3.1 of this paper for a discussion of the function of the imperfects in v. 38 .

${ }^{26}$ For other examples of sentences with presentational articulation with an imperfect as main verb, cf. Luke 2:36a, $13: 1,16: 19$, and $18: 2 b$.

${ }^{27}$ Cf. Levinsohn (2000: 135).

${ }^{28}$ For some more examples of the extensive pluperfect in the NT, cf. Mark 14:44: $\delta \varepsilon \delta \omega ́ \kappa \varepsilon l$ ("[the betrayer] had

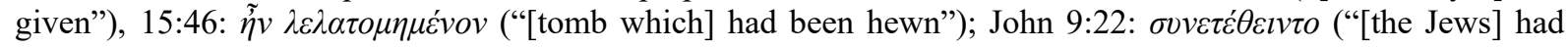

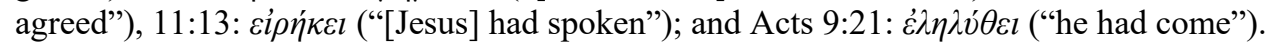




\subsection{Providing supplementary details}

The imperfect and pluperfect often occur in expressions which provide supplementary details. These expressions differ in several respects from those occurring in the setting for a narrative. For example, they occur inside the body of the narrative, and usually refer back to persons, events, etc. in the main storyline. They are usually short, and sometimes parenthetic, expressions. Some of the examples could also be classified as setting the scene. Consider the following passage:

\section{Luke 5:8-10b:}

Summary of background (Luke 5:6-7): After Simon Peter, James, and John had caught a great number of fish, their nets began to break. Their partners in the other boat came to their help. Both boats were filled with fish and began to sink.

\begin{tabular}{|c|c|}
\hline 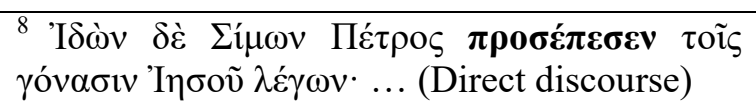 & $\begin{array}{l}{ }^{8} \text { When Simon Peter saw this, he fell down at } \\
\text { Jesus' knees and said ... (Direct discourse) }\end{array}$ \\
\hline 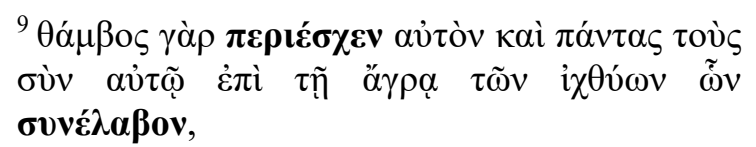 & $\begin{array}{l}{ }^{9} \text { For amazement had seized him and all those } \\
\text { with him because of the catch of fish which they } \\
\text { had taken, }\end{array}$ \\
\hline 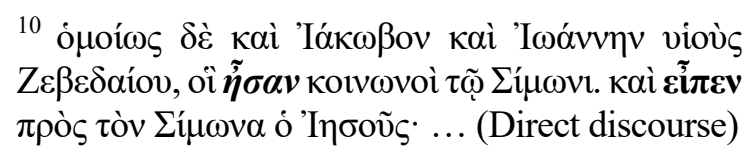 & $\begin{array}{l}{ }^{10} \text { and so also James and John, the sons of } \\
\text { Zebedee, who were partners of Simon. But } \\
\text { Jesus said to Simon ... (Direct discourse) }\end{array}$ \\
\hline
\end{tabular}

In this passage, v. 8, which contains the aorist indicative $\pi \rho o \sigma \varepsilon ́ \pi \varepsilon \sigma \varepsilon v$ ("he [Simon Peter] fell down"), continues the main storyline. Vv. 9 and 10a, which give an explanation for Simon Peter's behaviour and words in v. 8, are a non-event and as such background information. The appositive

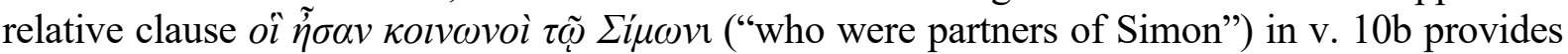

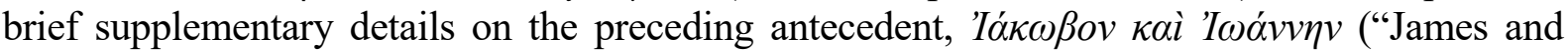
John"). Thereafter, the main storyline, which contains the aorist indicative $\varepsilon \tilde{i} \pi \varepsilon v$ ("he [Jesus]

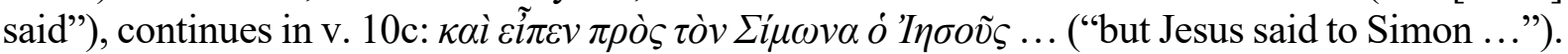

In some instances, the mainline story is briefly interrupted by supplementary details on persons who were not the main actors in the scene up to that point, whereafter the focus returns to the mainline story and main actors. Cf. the following passage:

\section{Luke 4:16c-21}

Summary of background (Luke 4:14-16b): Jesus returned to Galilee and began teaching in synagogues in the region. He came to Nazareth, where he had been brought up.

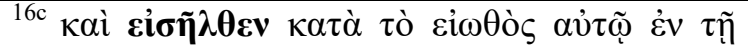

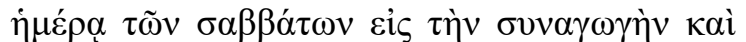

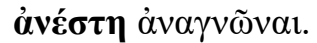

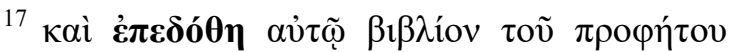

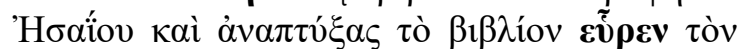

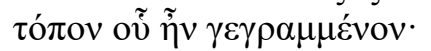

${ }^{18-19}$ Direct discourse
${ }^{16 c}$ And he went into the synagogue on the Sabbath day, as was his custom, and stood up to read.

${ }^{17}$ And the scroll of the prophet Isaiah was given to him. He unrolled the scroll and found the place where it was written, ${ }^{18-19}$ Direct discourse 


\begin{tabular}{|c|c|}
\hline 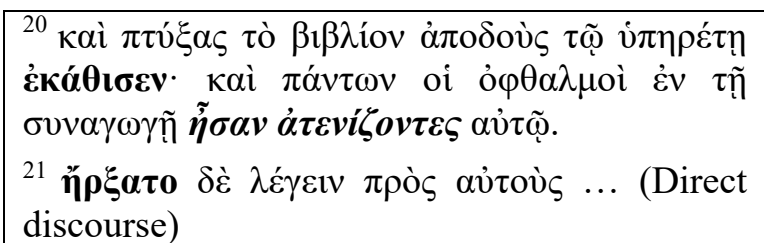 & $\begin{array}{l}{ }^{20} \text { He rolled up the book, gave it back to the } \\
\text { servant and sat down. The eyes of all in the } \\
\text { synagogue were staring at him. } \\
{ }^{21} \text { And he began to say to them ... (Direct } \\
\text { discourse) }\end{array}$ \\
\hline
\end{tabular}

In the first part of the mainline story (Luke 4:16c-20a), Jesus is the main actor. In this part, five aorist indicatives are used as main verbs: $\varepsilon i \sigma \tilde{\eta} \lambda \theta \varepsilon v$ ("he went into", v. 16c), $\dot{\alpha} v \varepsilon \dot{\sigma \tau \eta}$ ("he stood up", v. 16c), $\dot{\varepsilon} \pi \varepsilon \delta o ́ \theta \eta$ ("it [the scroll] was given to", v. 17a), $\varepsilon \tilde{v} \rho \varepsilon v$ ("he found", v. 17b), and $\dot{\varepsilon} \kappa \alpha \dot{\theta} l \sigma \varepsilon v$ ("he sat down", v. 20a). But before the sermon starts in v. 21, the focus moves briefly away from Jesus to the other people in the synagogue in the sentence $\kappa \alpha i$ $\pi \dot{\alpha} v \tau \omega v$ oi $\dot{\partial} \theta \theta \alpha \lambda \mu o i$ $\dot{\varepsilon} v \tau \tilde{\eta} \sigma v v \alpha \gamma \omega \gamma \tilde{\eta} \tilde{\eta} \sigma \alpha v \dot{\alpha} \tau \varepsilon v i \zeta o v \tau \varepsilon \varsigma \alpha \dot{v} \tau \tilde{\omega}$ ("and the eyes of all in the synagogue were staring at him", v. 20b). The sentence contains the periphrastic imperfect $\tilde{\eta} \sigma \alpha v \dot{\alpha} \tau \varepsilon v i \zeta o v \tau \varepsilon \varsigma$ ("they were staring at"), which is progressive, indicating an event taking place at the same time. The function of the sentence is to give supplementary information relating to the behaviour of the other people in the synagogue, and also to introduce them as participants in the rest of the story. Thereafter, the focus returns to the main actor, viz. Jesus, in v. 21.

The pluperfect also occurs a few times in Luke in similar situations, for example, in Luke 23:7-

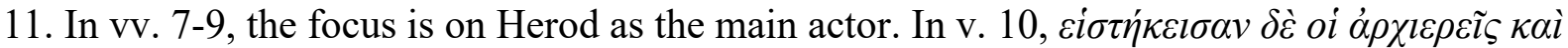

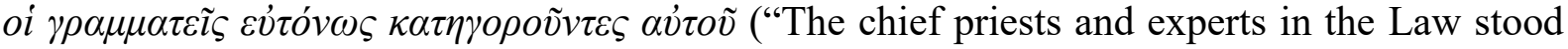
there, vehemently accusing them"), the focus turns briefly to the chief priests and experts in the

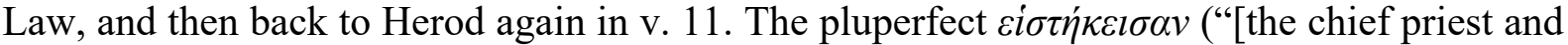

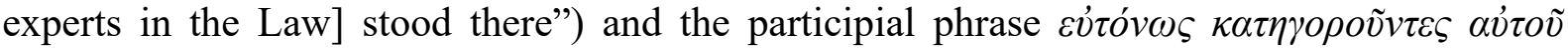
("vehemently accusing him") in v. 10 give brief background information on the behaviour of the chief priests and experts in the Law. The verb $\varepsilon i \sigma \tau \eta \dot{\kappa} \kappa l \sigma \alpha v$ ("stood") belongs to the category of verbs of which the pluperfect has the force of a simple past tense (cf. Wallace: 1996: 586). However, since it is lexically stative, it denotes background information. The same applies to $\varepsilon i \sigma \tau \dot{\eta} \kappa \varepsilon l$ ("[the crowd] stood") in Luke 23:35a, which appears together with the imperfect $\dot{\varepsilon} \xi \varepsilon \mu v \kappa \tau \eta \dot{\rho} \rho \zeta o v$ ("[the rulers] ridiculed").

In some instances, a passage contains more than one construction for indicating supplementary details. Cf. the following passage:

\section{$\underline{\text { Luke 23:50-53 }}$}

Summary of background (Luke 23:48-49): The crowds who had gathered to see the spectacle (i.e. the crucifixion) began to return. Jesus' acquaintances and the women who followed him from Galilee were standing at a distance, watching these things.

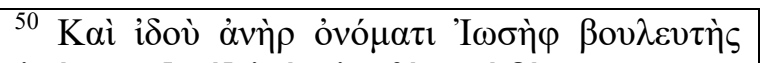

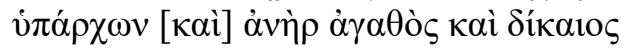

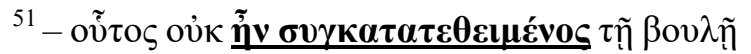

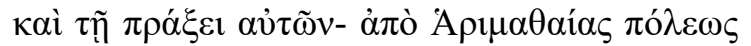

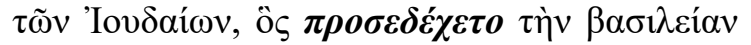

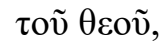

${ }^{50}$ Now there was a man named Joseph, a member of the Council and a good and righteous man

51 - he had not consented to their plan and action - from the Judean town of Arimathaea, who was waiting for the kingdom of God. 


\begin{tabular}{|c|c|}
\hline 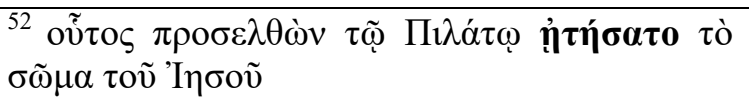 & ${ }^{52} \mathrm{He}$ went to Pilate and asked for the body of Jesus \\
\hline 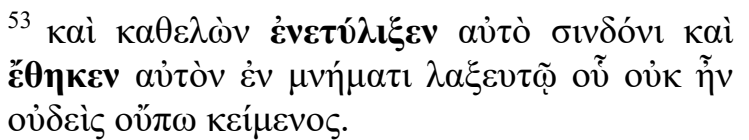 & $\begin{array}{l}53 \text { and after he had taken it down, he wrapped } \\
\text { it in a linen cloth and placed it in a tomb hewn } \\
\text { out of rock where no one had yet been laid. }\end{array}$ \\
\hline
\end{tabular}

In Luke 23:50, the attention prompter i $\delta o v$ ("look") highlights the introduction of Joseph, who is a new participant in the story. The flow of the sentence is then interrupted in v. 51a by the

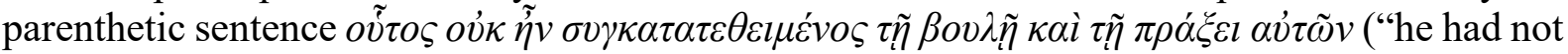
consented to their plan and action"), ${ }^{29}$ which refers back to Joseph and provides important supplementary details about his actions. The periphrastic pluperfect $\tilde{\eta} v \sigma v \gamma \kappa \alpha \tau \alpha \tau \varepsilon \theta \varepsilon \mu \mu \varepsilon v o \varsigma$ ("he consented") in v. 50 could be classified as extensive.

In Luke 23:51c, supplementary details are also given, this time by the appositive relative clause

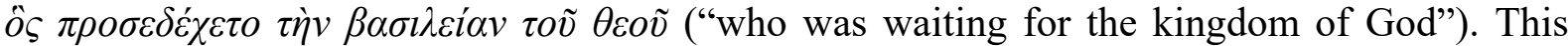
clause contains the imperfect $\pi \rho 0 \sigma \varepsilon \delta \varepsilon^{\prime} \chi \varepsilon \tau o$ ("he [Joseph] was waiting for"), which refers back and provides details on Joseph in the form of an ongoing state.

It should be noted that, in both instances of supplementary detail in v. 51, the information does not merely refer back to Joseph as a person, but also provides the background for his subsequent

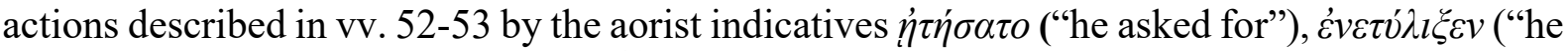
wrapped"), and $\varepsilon \theta \eta \kappa \varepsilon v$ ("he placed"). ${ }^{30}$

Although the imperfect and pluperfect often occur in expressions which provide supplementary

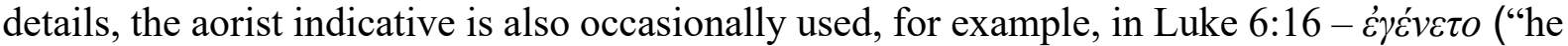

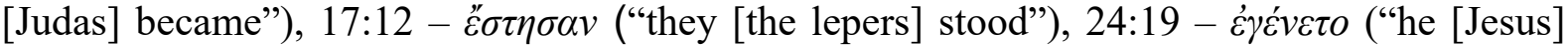
was"), etc. See also Acts 1:23-غं $\pi \varepsilon \kappa \lambda \dot{\eta} \theta \eta$ ("he [Barabbas] was also called").

\subsection{Explanation ${ }^{31}$}

Explanation in narrative is by nature a non-event and as such provides background information. Both the imperfect and the aorist indicative are often used in explanatory clauses in Luke. Cf. the following passage:

\footnotetext{
${ }^{29}$ This sentence is indicated as a parenthesis in the Nestle-Aland 28 text used here, as well as in The Holy Bible: King James Version ([1611], 1769), Die Bybel: 1933/1953 translation, The New English Translation (2006), and The New American Standard Bible (1995). Cf. Blass and Debrunner (1967: 243) on parenthetic remarks. Cf. also the reference to Robertson (1919: 904-905, in Wallace 1996: 585, fn. 36) with regard to the use of the pluperfect in the Gospel of John: "John does, as a matter of fact, use the past perfect [pluperfect] more frequently than do the Synoptists. He uses it to take the reader 'behind the scenes', and often throws it in by way of parenthesis". Wallace (ibid.) continues: "More recent grammarians would describe this usage as backgrounding [original italics] tense usage".

${ }^{30}$ Appositive relative clauses with an imperfect (or pluperfect) as main verb are often used in Luke to give supplementary detail on persons, time, the physical environment, etc. For example, 4:16 (pluperfect), 5:3 (imperfect), 8:2b (pluperfect), 8:3 (imperfect), 8:38 (pluperfect), 9:30 (imperfect), and 23:55 (periphrastic pluperfect). Cf. also the examples in Acts 9:33 (periphrastic pluperfect) and 18:7 (periphrastic imperfect). The Gospel of John often uses short, independent sentences with an imperfect for this purpose, for example, 1:39: $\tilde{\omega} \rho \alpha \tilde{\eta} v \dot{\omega} \varsigma \delta \varepsilon \kappa \alpha \dot{\tau} \tau$ ("it was the

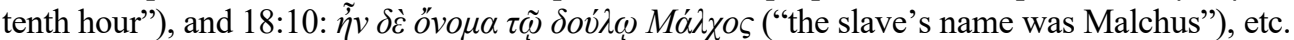

${ }^{31}$ The term "explanation" could be defined as information that "clarifies and explains the events of a narrative" (Levinsohn 2005: 69).
} 


\section{Luke 9:13-14}

Summary of background (Luke 9:11b-12): Jesus spoke to the crowds about the kingdom of God and cured those who had need of healing. The day was drawing to a close, and the disciples asked Jesus to send the crowd away to find lodging and food.

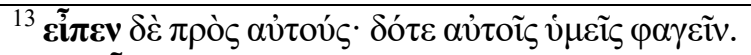

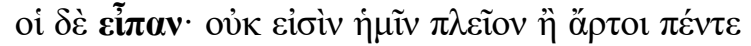

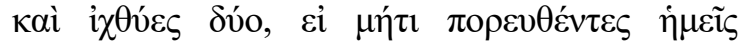

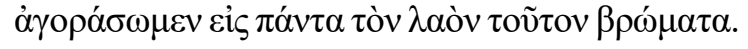

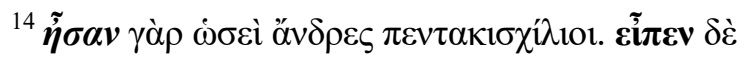

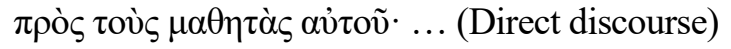

${ }^{13}$ But he said to them, "You should give them something to eat." But they said, "We have no more than five loaves and two fish, unless we go and buy food ourselves for all these people."

${ }^{14}$ For there were about five thousand men. And he said to his disciples ... (Direct discourse)

The discussion between Jesus and the disciples, which is the mainline story, continues in v. 13, where two aorist indicatives, $\varepsilon \tilde{i} \pi \varepsilon v$ ("he said") and $\varepsilon \tilde{i} \pi \alpha v$ ("they said"), are used to introduce Jesus' words and the disciples' answer, respectively. This is followed by the short sentence in

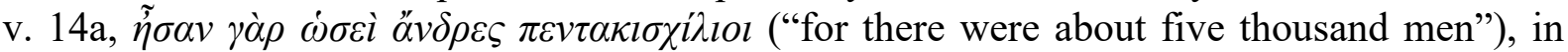
which the imperfect $\tilde{\eta} \sigma \alpha v$ ("there were") is used. ${ }^{32}$ The sentence explains the reason for the disciples' reaction (v. 13d) to the instruction Jesus gave them (v. 13a). ${ }^{33}$ Thereafter, the discussion continues in v. 14b, where the aorist indicative $\varepsilon \tilde{i} \pi \varepsilon v$ ("he said") introduces Jesus' further instructions to the disciples. ${ }^{34}$

The only example of a pluperfect in an explanatory clause in Luke's narrative proper seems to be $\eta \eta \delta \varepsilon l \sigma \alpha v$ ("they knew") in 4:41 - the verb oĩ $\delta \alpha$ ("I know") belongs to the group of verbs of which the perfect and pluperfect tenses do not have the usual aspectual characteristics, but have a simple present and past force. Since $\eta \delta \varepsilon l \sigma \alpha \nu$ ("they knew") is lexically stative, it denotes background. ${ }^{35}$

The aorist indicative is also used in a number of explanatory expressions in Luke, for example, in 5:9, 8:29a, 10:42b, 20:19c, and 22:2b. The aorist indicative differs from the imperfect as the former merely states the occurrence of the event of explanation in the past, whereas the latter signifies an event, state, etc. which is in progress in the past.

\footnotetext{
32 Some translations treat Luke 9:14a as a parenthesis, enclosing it in brackets. Cf., for example, The New American Standard Bible (1995), New English Translation (2006), and The Holy Bible: The New International Version (2011).

${ }^{33}$ The function of the connective $\gamma \dot{\alpha} \rho$ ("for") is "to signal that what follows strengthens a preceding assertion" (Levinsohn 2006: 19).

${ }^{34}$ Other examples of the use of the imperfect in explanatory clauses in Luke are 4:32b, 6:19b, 9:14a, and 19:3b. Cf. also the following examples from the Gospel of John: (i) 2:21: Here, the sentence containing the imperfect É $\lambda \varepsilon \gamma \varepsilon v$ ("he was talking") explains the content of Jesus' words in v. 19b (Du Toit 2017: 226); and (ii) 8:6: the sentence with the imperfect $\check{c} \lambda \varepsilon \gamma o v$ ("they were saying") explains the reason for the words of the scribes and Pharisees to Jesus in vv. 4b-5 (Du Toit 2017: 227).

${ }^{35}$ See Wallace (1996: 586).
} 


\subsection{Use in epilogues ${ }^{36}$}

An epilogue in narrative discourse is also a non-event by nature and presents background information. The imperfect, but not the pluperfect, occurs in several instances in Luke with this function. Cf. the following passages:

\section{Luke 2:39-40}

Summary of background (Luke 2:22-38): Jesus' parents had brought him to Jerusalem to present him to the Lord. They were blessed by Simeon. A prophetess, Anna, began to praise God and speak about Jesus.

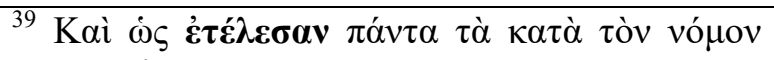

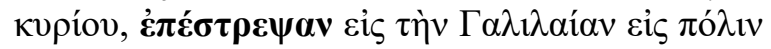
$\dot{\varepsilon} \alpha v \tau \tilde{\omega} \nu \mathrm{N} \alpha \zeta \alpha \rho \varepsilon \dot{\theta}$.

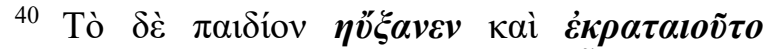

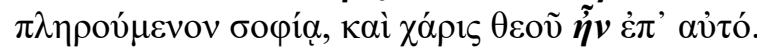

${ }^{39}$ And when they had completed everything according to the law of the Lord, they returned to Galilee, to their own town of Nazareth.

${ }^{40}$ And the child continued to grow and became strong, increasing in wisdom, and the grace of God was upon him.

The mainline story continues in Luke 2:39, signalled by the use of two aorist indicatives $\dot{\varepsilon} \tau \dot{\varepsilon} \lambda \varepsilon \sigma \alpha \nu$ ("they completed") and $\dot{\varepsilon} \pi \varepsilon \dot{\sigma} \sigma \rho \varepsilon \psi \alpha \nu$ ("they returned"). In the epilogue of the story (v. 40), a summary is given of Jesus' youth in which three progressive imperfects are used - $\eta \bar{v} \xi \alpha v \varepsilon v$

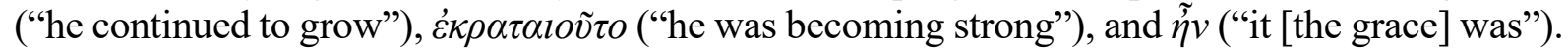

The use of the imperfects in the epilogue also creates an expectation of something about to happen, and thus promotes cohesion in the text. The events below in Luke 2:41-52, which is about the boy Jesus in the temple, take place 12 years later, and give an example of Jesus' growth and wisdom. This fulfils part of the expectations created by the use of the imperfects in Luke 2:40. However, the structure of the epilogue in this passage is somewhat different.

\section{Luke 2:51-52}

Summary of background (Luke 2:41-50): Jesus' parents went to Jerusalem every year for the Feast of the Passover, and also when he was 12 years old. After the festival, Jesus stayed behind in Jerusalem. His parents went back and found him in the temple among the teachers. His mother asked why he had treated his parents in this way. He answered that he had to be in his Father's house. His parents did not understand the answer.

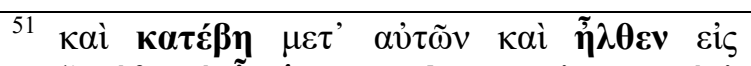

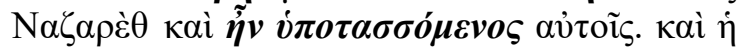

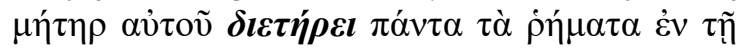

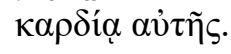

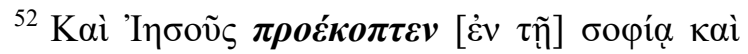

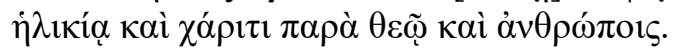

${ }^{51}$ And he went down with them and came to Nazareth and was obedient to them. And his mother kept all these events in her heart.

52 And Jesus kept increasing in wisdom and stature and in favour with God and people.

\footnotetext{
36 The term "epilogue" or "coda" refers to a final, non-event section "that makes a meta-comment on the story, gives a summary, or gives some post-resolution information about the characters" (Brewer 1985: 183, in Dooley and Levinsohn 2000: 54).
} 
The coordinate sentence $\kappa \alpha i ̀ ~ \kappa \alpha \tau \varepsilon \dot{\beta} \beta \eta \mu \varepsilon \tau$ ' $\alpha \dot{v} \tau \tilde{\omega} v \kappa \alpha i \tilde{\eta} \lambda \theta \varepsilon v \varepsilon \dot{i} \varsigma N \alpha \zeta \alpha \rho \varepsilon \dot{\theta} \theta$ ("and he went down with them and came to Nazareth") in Luke 2:51 is the last part of the mainline story that began in Luke $2: 41$, and contains the aorist indicatives $\kappa \alpha \tau \dot{\varepsilon} \beta \eta$ ("he went down") and $\tilde{\eta} \lambda \theta \varepsilon v$ ("he came").

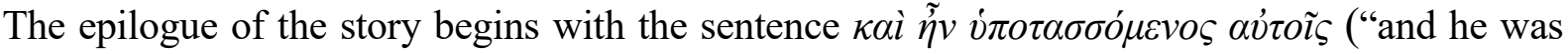
obedient to them") in Luke 2:51 and ends at the end of v. 52. The epilogue consists of two parts. The first part contains two post-resolution comments about characters in the preceding story, viz.

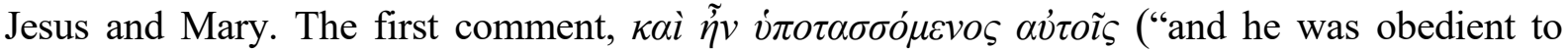
them"), refers to Jesus' behaviour towards his parents after their return to Nazareth, in the aftermath of the events in Jerusalem. The second comment is about Mary - $\alpha \alpha \dot{i} \dot{\eta} \mu \dot{\eta} \tau \eta \rho \alpha \dot{v} \tau o \tilde{v}$ $\delta l \varepsilon \tau \dot{\eta} \rho \varepsilon l \pi \dot{\alpha} v \tau \alpha \tau \dot{\alpha} \dot{\rho} \eta \dot{\eta} \mu \alpha \alpha \alpha \dot{\varepsilon} v \tau \tilde{\eta} \tilde{\eta} \alpha \rho \delta i \alpha \alpha \alpha \dot{v} \tau \tilde{\eta} \varsigma$ ("and his mother kept all these events in her heart"). ${ }^{37}$ The second part of the epilogue (Luke 2:52) contains a summary of the next period in Jesus' life. The use of the imperfects creates an expectation of something about to happen and promotes cohesion in the text by keeping the story about Jesus running in the background during the following scene where the focus temporarily swings back to John the Baptist (Luke 3:1-20). The story about Jesus is picked up again in v. 3:21 with his baptism 18 years later.

This part of the epilogue is similar in content to the epilogue in Luke 2:40 discussed above, as

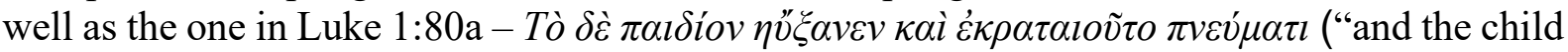
continued to grow and became strong in spirit") - which follows on the story about the birth of John the Baptist (Luke 1:57-66) and Zechariah's song (Luke 1:67-78).

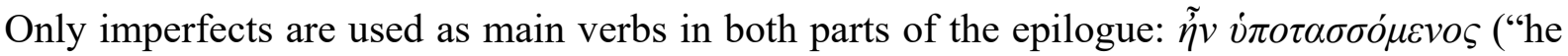
[Jesus] was obedient") and $\delta \imath \varepsilon \tau \eta \dot{\rho} \rho \varepsilon l$ ("she [his mother] kept") in the first part of the epilogue (v.

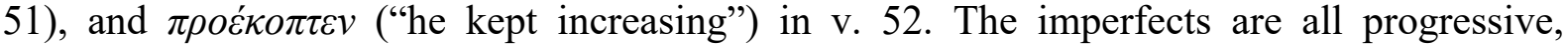
indicating states continuing in the past. This fits well with the provision of background information in the epilogue.

\section{The function of the imperfect to indicate foreground information}

All the examples discussed so far illustrate the imperfect's ability to indicate various types of background information in Luke's narrative proper. However, there are instances where the imperfect seems to denote foreground. Levinsohn (2000: 174) regards the use of the imperfects in Luke 2:38 as an example of this, and points out that although the imperfect tends to correlate with background information in narrative, "it is not [original italics] a signal that the information concerned is necessarily of a background nature". Luke 2:38 is discussed below in the broader context of Luke 2:36-39.

\section{$\underline{\text { Luke 2:36-39 }}$}

Preceding events: After Simeon had blessed Joseph, Mary, and Jesus, he spoke to Mary (vv. 3435). This is followed by the passage below.

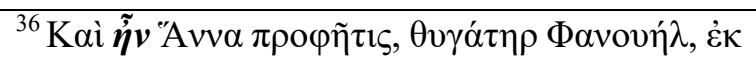

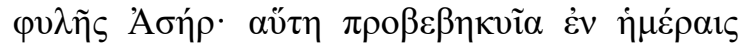

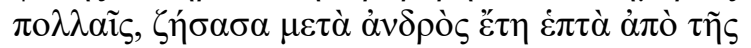

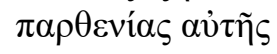

36 And there was a prophetess, Anna, the daughter of Phanuel, of the tribe of Asher. She was very advanced in years, having lived with a husband seven years since she was a virgin.

\footnotetext{
${ }^{37}$ For a similar comment about Mary, cf. Luke 2:19.
} 


\begin{tabular}{|c|c|}
\hline 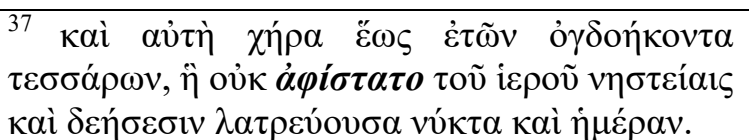 & $\begin{array}{l}{ }^{37} \text { and she was a widow until she was eighty-four, } \\
\text { and did not leave the temple and worshipped day } \\
\text { and night with fasting and prayer. }\end{array}$ \\
\hline 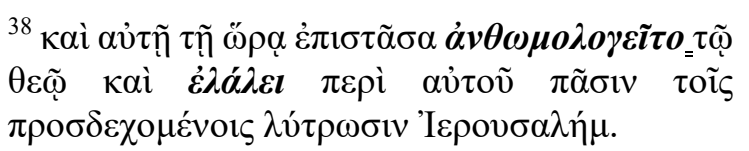 & $\begin{array}{l}{ }^{38} \text { And at that very moment she came up and began } \\
\text { praising God and speaking about him to all who } \\
\text { were waiting for the redemption of Jerusalem. }\end{array}$ \\
\hline 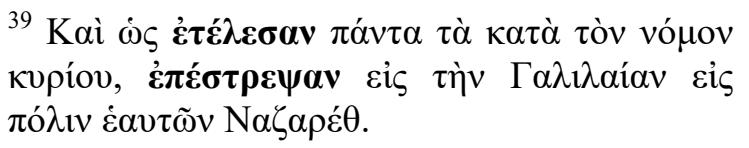 & $\begin{array}{l}{ }^{39} \text { And when they had completed a } \\
\text { according to the law of the Lord, they } \\
\text { to Galilee, to their city, Nazareth. }\end{array}$ \\
\hline
\end{tabular}

A new scene begins in v. 36 in which Anna, the prophetess, is the main actor, and it ends in v. 38. Thereafter, the focus shifts to Joseph, Mary, and Jesus' return to Nazareth (v. 39).

In the story about Anna (vv. 36-38), all the verbs in the indicative mood are imperfects: v. 36a: $\tilde{\eta} v$ ("there was"), v. 37b: $\alpha \varphi i \sigma \tau \alpha \tau o$ ("she left"), and v. 38: $\alpha \nu \theta \omega \mu о \lambda o \gamma \varepsilon i \tau o$ ("she began praising") and $\dot{\varepsilon} \lambda \dot{\alpha} \lambda \varepsilon l$ ("she began speaking"). In v. 36a, the imperfect $\tilde{\eta} v$ ("there was") is used in the introduction of a new participant in the story - viz. the prophetess, Anna - and to set the first part of the scene for the events in v. 38. The scene is further set in v. 36b by means

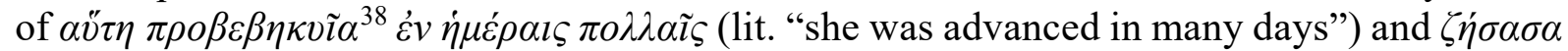
$\mu \varepsilon \tau \grave{\alpha} \dot{\alpha} v \delta \rho \dot{o} \varsigma$ हैं $\eta \dot{\varepsilon} \pi \tau \grave{\alpha} \dot{\alpha} \pi \dot{o} \tau \tilde{\eta} \varsigma \pi \alpha \rho \theta \varepsilon v i \alpha \varsigma \alpha \dot{v} \tau \tilde{\eta} \varsigma$ ("having lived with a husband seven years since the time she was a virgin"). In v. 37, the last part of the scene is set by means of the

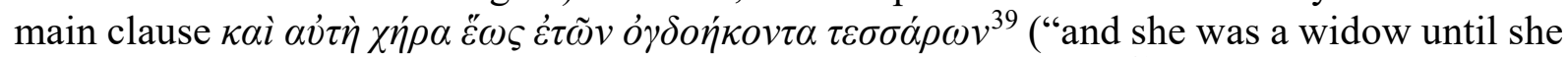

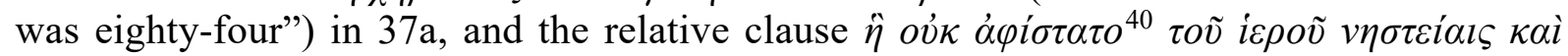

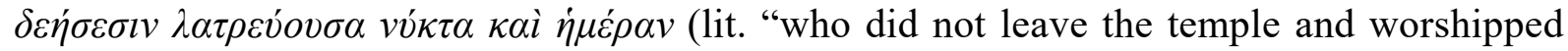
day and night with fasting and prayer").

In v. 38, two imperfects occur, viz. $\dot{\alpha} v \theta \omega \mu о \lambda о \gamma \varepsilon \tilde{\imath} \tau o$ ("she began to worship") and $\dot{\varepsilon} \lambda \dot{\alpha} \lambda \varepsilon l$ ("she began to speak"). These are best taken as ingressive, stressing the beginning of the action in the past, with the implication that the action continued for some time. ${ }^{41}$ Levinsohn is correct in viewing these imperfects as denoting foreground, especially in view of the fact that v. 38 is the last part of the story about Anna. The events in v. 38 could even be regarded as the climax of the story.

The following are further examples where the imperfect seems to denote foreground in Luke:

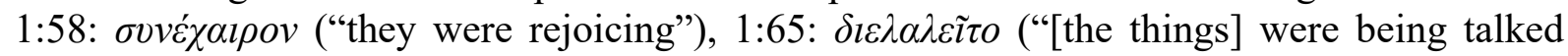
about"), 9:43: $\dot{\varepsilon} \xi \varepsilon \pi \lambda \dot{\eta} \sigma \sigma o v \tau o$ (“[all] were amazed"), 18:43: $\dot{\eta} \kappa o \lambda o v ́ \theta \varepsilon l$ ("he started following”), and 23:42: "̈ $\lambda \varepsilon \gamma \varepsilon v$ ("he said"). ${ }^{42}$

These examples support the view that the relationship between the imperfect and background information in narrative proper in Luke is one of correlation rather than strict equivalence. ${ }^{43}$

\footnotetext{
${ }^{38}$ The verb $\tilde{\eta} v$ ("she was") is understood. The phrase $\tilde{\eta} v \pi \rho o \beta \varepsilon \beta \eta \kappa v \tilde{\alpha} \alpha$ ("she was advanced") is an intensive periphrastic pluperfect denoting background information.

39 The verb $\tilde{\eta} v$ ("was") is also understood here.

40 The imperfect $\dot{\alpha} \varphi i \sigma \tau \alpha \tau o$ ("she left") denotes habitual action, as does the imperfect participle $\lambda \alpha \tau \rho \varepsilon v ́ o v \sigma \alpha$ ("worshipping").

${ }^{41}$ Cf. Wallace (1996: 544).

${ }^{42}$ According to Wallace (1996: 542), č $\lambda \varepsilon \gamma \varepsilon v$ ("he said") is in this case an example of the rare instantaneous imperfect with the meaning of an aorist indicative. He continues: "The imperfect is used [here] to introduce a vivid, emotionallycharged statement. As such, it may be termed a dramatic [original italics] imperfect" (Wallace 1996: 543).

${ }^{43}$ Cf. also Hopper (1979b: 215-216, in Levinsohn 2000: 174).
} 


\section{Findings}

\subsection{The imperfect}

The imperfect is the primary tense-form used in Luke's narrative discourse to give background information. This is related to the imperfect's "imperfective" aspect and characteristic linking to another verbal utterance, which also promotes cohesion in the text. The imperfect gives foreground information in a few instances. This supports the view that the relationship between the imperfect and background information in narrative discourse in Luke is one of correlation rather than strict equivalence.

Setting the scene for events that follow in the mainline story seems to be the main specific use of the imperfect for background information in Luke. A narrative pattern that often occurs in

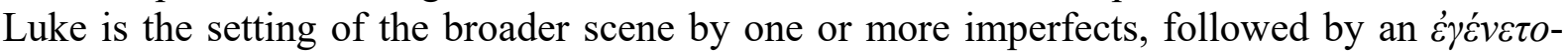
construction which indicates a transition and narrows down the setting to more specific circumstances. Thereafter, the mainline story begins, carried by aorist indicatives and/or historical presents. The correlation between the imperfect and background information is particularly strong in cases where the scene is set.

The imperfect is often used to provide supplementary details about persons, events, etc. in the main storyline in the form of short, sometimes parenthetic, expressions which refer back to persons, places, etc. Some of these expressions could also be classified as setting the scene or providing an explanation. They usually do not appear at the beginning of a scene, but inside the body of the main narrative. In a few instances, the mainline story is briefly interrupted by supplementary details about persons who were not the main actors up to that point, whereafter the focus returns to the mainline story and main actors. The aorist indicative is also occasionally used in expressions in Luke that provide supplementary information.

The imperfect also occurs in sentences with presentational articulation to introduce participants in the story. The attention prompter $i \delta o v$ ("look") sometimes co-occurs with the imperfect in order to highlight the introduction. In a few instances, the introduction of a participant and the (first part of the) setting are done in the same sentence at the beginning of a scene.

The imperfect occurs only in a few instances in epilogues in Luke. Again, these are nonevents by nature and present background information. The epilogues either consist of postresolution information about characters in the preceding story, or give a summary of what took place afterwards. In some instances, both elements form part of the same epilogue. All the imperfects in the epilogues indicate states that continued in the past. The use of the imperfect in these cases also creates an expectation of something about to happen and thus promotes cohesion in the text.

The imperfect is sometimes used in explanatory clauses. Explanation in narrative is by nature a non-event and as such also provides background information. 


\subsection{The pluperfect}

The pluperfect occurs only 16 times in Luke, and indicates background information in all cases. This is related to the pluperfect's characteristic of describing a continuing state in the past which is the result of an event in the past. The pluperfect has the following specific background uses:

(i) It occurs in a few instances together with one or more imperfects in setting the scene for the mainline events that follow;

(ii) It is used in a number of instances to provide supplementary details about persons, events, etc. in the main storyline. In this use, the pluperfect always refers backwards, for example, when it occurs in an appositive relative clause. In a few instances, the pluperfect provides supplementary details about persons who were not the main actors in the story up to that point, whereafter the focus returns to the mainline story and actors;

(iii) The only example of the use of the pluperfect in an explanatory clause in Luke seems to be $\eta \delta \varepsilon l \sigma \alpha v$ ("they knew", Luke 4:41). This verb indicates background information, not on account of the pluperfect's usual aspectual characteristics, but because $\eta \delta \varepsilon l \sigma \alpha v$ ("they knew") is lexically a stative verb.

\section{References}

Aland, B., K. Aland, J. Karavidopoulos, C.M. Martini, and B.M. Metzger (eds.) in cooperation with the Institute for New Testament Textual Research, Münster. 2012. Nestle-Aland Novum Testamentum Graece, 28th Revised Edition. Stuttgart: Deutsche Bibelgesellschaft.

Bakker, W.F. 1966. The Greek imperative. An investigation into the aspectual differences between the present and aorist imperatives in Greek prayer from Homer up to the present day. Amsterdam: Hakkert.

Blass, F. and A. Debrunner. [1913] 1967. A Greek grammar of the New Testament and other early Christian literature. [Translation and review of the $9^{\text {th }}-10^{\text {th }}$ German edition, Grammatik des neutestamentlichen Griechisch by R.W. Funk, incorporating supplementary notes of A. Debrunner.] Chicago, IL: The University of Chicago Press / Toronto: The University of Toronto Press.

Brewer, W.F. 1985. The story schema: Universal and culture-specific properties. In D.R. Olson, N. Torrance, and A. Hildyard (eds.) Literacy, language, and learning: The nature and consequences of reading and writing. Cambridge: Cambridge University Press. pp. 167-194.

Callow, K. 1974. Discourse considerations in translating the Word of God. Grand Rapids, MI: Zondervan.

Campbell, C.R. 2007. Verbal aspect, the indicative mood, and narrative: Soundings in the Greek of the New Testament. New York: Peter Lang. 
Campbell, C.R. 2008. Verbal aspect and non-indicative verbs: Further soundings in the Greek of the New Testament. New York: Peter Lang.

Decker, R.J. 2013. The function of the imperfect tense in Mark's Gospel. In S.E. Porter and A.W. Pitts (eds.) The language of the New Testament: Context, history and development. Leiden: Brill. pp. 347-364. https://doi.org/10.1163/9789004236400_015

Die Bybel: 1933/1953 translation. Kempton Park: Bible Society of South Africa.

Die Bybel: 1983 translation. Kempton Park: Bible Society of South Africa.

Dooley, R.A. and S.H. Levinsohn. 2000. Analyzing discourse: A manual of basic concepts. Dallas, TX: SIL International.

Dry, H.A. 1992. Foregrounding: An assessment. In S.J.J. Hwang and W.R. Merrifield (eds.) Language in context: Essays for Robert E. Longacre. Dallas, TX: Summer Institute of Linguistics and University of Texas at Arlington. pp. 435-440.

Du Toit, H.C. 2017. The function of the imperfect tense-form in the narrative discourse of John's Gospel: Some remarks. Neotestamentica 51(2): 209-234. https://doi.org/10.1353/ $\underline{\text { neo.2017.0012 }}$

Fanning, B.M. 1990. Verbal aspect in New Testament Greek. Oxford: Clarendon.

Fleischmann, S. 1985. Discourse functions of tense-aspect oppositions in narrative: Toward a theory of grounding. Linguistics 23(6): 851-852. https://doi.org/10.1515/ling.1985.23.6.851

Grimes, J.E. 1975. The thread of discourse. The Hague: Mouton.

Hopper P.J. 1979a. Some observations on the typology of focus and aspect in narrative language. Studies in Language 3(1): 37-46.

Hopper P.J. 1979b. Aspect and foregrounding in discourse. In T. Givón (ed.) Discourse and syntax. New York: Academic Press. pp. 213-241. https://doi.org/10.1163/9789004368897010

Hopper, P.J. and Thompson, S.A. 1980. Transitivity in grammar and discourse. Language 56: 251-299. https://doi.org/10.2307/413757

Johnson, C.E. 2010. A discourse analysis of the periphrastic imperfect in the Greek New Testament writings of Luke. Ann Arbor, MI: UMI Dissertation Publishing.

Levinsohn, S.H. 2000. Discourse features of New Testament Greek: A coursebook on the information structure of New Testament Greek. Dallas, TX: SIL International.

Levinsohn, S.H. 2005. Self-instruction materials on narrative discourse analysis. Available online: https://www.sil.org/resources/archives/68643. (Accessed 11 July 2020). 
Levinsohn, S.H. 2006. The relevance of Greek discourse studies to exegesis. Journal of Translation 2(2): 11-21.

Mathewson, D.L. 2008. Verbal aspect in the Apocalypse of John: An analysis of Revelation 5. Novum Testamentum 50(1): 58-77. https://doi.org/10.1163/156853607x186013

Mathewson, D.L. 2010. Verbal aspect in the Book of Revelation: The function of Greek verb tenses in John's Apocalypse. Leiden: Brill.

McKay, K.L. 1994. A new syntax of the verb in New Testament Greek: An aspectual approach. New York: Peter Lang.

New American Bible. 2010. Washington, DC: Confraternity of Christian Doctrine.

Newman, B.M. and E.A. Nida. 1972. A translator's handbook on the Acts of the Apostles. London: United Bible Societies.

Nuwe Testament en Psalms: 'n Direkte Vertaling. 2014. Bellville: Bible Society of South Africa.

Pennington, J.T. and G. Van Court. 2006. Aspectual Prominence in Matthew. Paper presented at the Society of Biblical Literature conference, Washington, DC, 18-21 November.

Porter, S.E. 1989. Verbal aspect in the Greek of the New Testament, with reference to tense and mood. New York: Peter Lang. https://doi.org/10.3726/978-1-4539-0994-2

Porter, S.E. 1994. Idioms of the Greek New Testament. Sheffield: Sheffield Academic Press.

Rijksbaron, A. 1988. The discourse function of the imperfect. In A. Rijksbaron, H.A. Mulder, and G.C. Wakker (eds.) In the footsteps of Raphael Kühner. Proceedings of the International Colloquium in commemoration of the $150^{\text {th }}$ anniversary of the publication of Raphael Kühner's 'Ausführliche Grammatik der Griechischen Sprache, II. Teil: Syntax'. Amsterdam: J.C. Gieben. pp. 237-254.

Robertson, A.T. 1919. A grammar of the Greek New Testament in the light of historical research. Cambridge: Cambridge University Press.

Seiler, H. 1952. L’aspect et le temps dans le verb néo-grec. Paris: Belles Lettres.

Talmy, L. 1978. Figure and ground in complex sentences. In J.H. Greenberg (ed.) Universals of human language Vol. 4: Syntax. Stanford, CA: Stanford University Press. pp. 625-649.

The Holy Bible: English Standard Version. 2011. Wheaton: Good News Publishers.

The Holy Bible: King James Version. [1611], 1769. Copyright (C 1988-1997 by the Online Bible Foundation and Woodside Fellowship of Ontario, Canada. 
The Holy Bible: New International Version. 2011. Grand Rapids, MI: Zondervan Publishing House.

The Holy Bible: New King James Version. 1982. Nashville, TN: Thomas Nelson Inc.

The Holy Bible: New Living Translation. 2007. Wheaton, IL: Tyndale House Publishers.

The Holy Bible: New Revised Standard Version of the Bible. 1989. Peabody, MA: Hendrickson Publishers.

The New American Standard Bible. 1995. La Habra, CA: The Lockman Foundation.

The New English Translation. 2006. Richardson, TX: Biblical Studies Press, LLC.

The New Jerusalem Bible. Reader's Edition. 1990. New York: Doubleday.

Wallace, D.B. 1996. Greek grammar beyond the basics: An exegetical syntax of the New Testament. Grand Rapids, MI: Zondervan Publishing House. 